\title{
PROCESY EMANCYPACYJNE FILMOWEGO GATUNKU SF W POWOJENNEJ CZECHOSŁOWACJI A LEMOWSKIE REPERKUSJE. WSTĘPNY REKONESANS
}

\author{
JACEK NOWAKOWSKI ${ }^{1}$ \\ (Uniwersytet im. Adama Mickiewicza w Poznaniu)
}

Słowa kluczowe: fantastyka, Stanisław Lem, adaptacja filmowa, literatura SF, film czeski

Key words: sci-fi, Stanisław Lem, adaptation, sci-fi literature, Czech film

\begin{abstract}
Abstrakt: Jacek Nowakowski. PROCESY EMANCYPACYJNE FILMOWEGO GATUNKU SF W POWOJENNEJ CZECHOSŁOWACJI A LEMOWSKIE REPERKUSJE. WSTĘPNY REKONESANS. „PORÓWNANIA” 17, 2015. T. XVII. S. 67-75. ISSN 1733-165X. Artykuł przedstawia pierwsze ważne filmy science fiction powstałe w Czechosłowacji w trzech dekadach - latach 40., 50. oraz 60. ubiegłego wieku, pokazując, że stanowią one podwaliny tego typu kina u naszych południowych sąsiadów. Wszystkie realizują odmienny model ekranowej fantastyki, lecz w odróżnieniu od Krakatit (1948). Otakara Vávry nadającego mu rys pesymizmu, inny od humanistycznego optymizmu literackiego pierwowzoru (powieść K. Čapka) i wtłaczającego go w kontekst powojennych zagrożeń atomowych, a także feerycznego, pełnego wdzięku XIX-wiecznej grawiury ilustrującej powieści Julesa Verne'a filmu Karela Zemana Diabelski wynalazek (1958), to właśnie najpóźniej powstała (niezaznaczona w napisach czołowych) adaptacja powieści Stanisława Lema Obłok Magellana, zatytułowana - Ikaria XB-1 (1963) w reżyserii J. Poláka okazał się najbardziej nowoczesnym, bo stawiającym na realizm, utworem czeskiego kina SF tamtego okresu.
\end{abstract}

Abstract: Jacek Nowakowski, EMANCIPATORY PROCESSES OF THE SCI-FI FILM IN POSTWAR CZECHOSLOVAKIA AND ITS REPERCUSSIONS IN LEM. AN INTRODUCTIORY INVESTIGATION. "PORÓWNANIA" 17, 2015. Vol. XVII. P. 67-75. ISSN 1733-165X. The article

\footnotetext{
${ }^{1}$ Correspondence Address: janow@amu.edu.pl
} 
presents the first important science fiction films made in Czechoslovakia in three decades, 40s, 50s and 60 s of the 20th century, in order to show that they constitute the basis of this type of cinematography in Poland's southern neighbour. They reflect various models of film fantasy from a pessimistic note in Krakatit (1948) by Otakar Vávra, different from the humanistic optimism of its literary prototype (novel by K. Čapek) put in the context of the post-war nuclear threats to a vivid and graceful 19th century gravure illustrating the novels of Jules Verne in the film by Karel Zeman Vynález zkázy (1958). The last to be made was an adaptation of Stanisław Lem's novel Obłok Magellana, titled - Ikaria XB-1 (1963) (not mentioned in the opening credits) directed by J. Polák which turned out to be the most modern sci-fi film of the times because of its realism.

W niniejszym artykule interesować mnie będą narodziny nowoczesnego filmu science fiction $\mathrm{w}$ powojennej Czechosłowacji, za jaki uważam film Ikaria XB-1 (1963) Jindřicha Poláka, w kraju o bogatych tradycjach fantastyki filmowej. Kontekstem dla tego utworu i mych rozważań będą dwa inne, wcześniejsze filmy z szeroko rozumianej formuły fantastyczno-naukowej, mianowicie Krakatit (1948) Otakara Vávry oraz Diabelski wynalazek (1958) Karela Zemana, reprezentujące odmienne typy fantastyki, a w przypadku ostatniego reżysera, także wyraziste podejście autorskie. Ponadto wszystkie trzy filmy to adaptacje znanych utworów ze światowego i rodzimego kanonu literatury tego rodzaju. Każdy z nich jednak reprezentuje odrębne podejścia do zabiegu adaptacji. Rzecz jasna, zgodnie $\mathrm{z}$ tematem artykułu, wątek transpozycji utworu literackiego na ekran kinowy zajmować mnie będzie przy okazji przeniesienia na ekran Obłoku Magellana (1955) Stanisława Lema przez Jindřicha Poláka, co nie znaczy, że dwa pozostałe przypadki nie będą charakteryzowane pod tym względem. I tak film Otokara Vávry jest adaptacją powieści czeskiego pisarza Karela Čapka, Krakatit, pochodzącej z roku 1924. Utwór Zemana natomiast to filmowy wariant powieści klasyka francuskiej i światowej fantastyki, Julesa Verne'a Twarza do sztandaru (1896), znanej w Polsce jako Straszny wynalazca (w tłumaczeniu Karoliny Bobrowskiej), należącej do rozległego cyklu Niezwykłe podróże.

Kiedy w 1948 roku Otakar Vávra filmował powieść wybitnego czechosłowackiego pisarza, kino, jak i inne dziedziny kultury i sztuki naszych południowych sąsiadów, przeżywało ostatnie chwile swobody przed przejęciem władzy przez komunistów. Przedwojenne sukcesy Josefa Rovenskiego (Rzeka, 1934), Gustawa Machatý'ego (Ekstaza, 1933), Martina Friča (Janosik, 1935), a także samego Vávry (Cech panien kutnohorskich, 1938), zdawały się dobrze wróżyć tej kinematografii. Okazało się, że nawet II wojna światowa nie osłabiła znacząco jej pozycji, a wkrótce po powojennej nacjonalizacji przemysłu filmowego i utworzeniu szkoły filmowej FAMU w Pradze czechosłowackie kino zaczęło odnosić dalsze sukcesy. Na 
krótko jednak. Niewykluczone, że łabędzim śpiewem tego czasu okazał się - obok Dalekiej drogi (1949) Alfreda Radoka, poświęconej tematowi zagłady czeskich Żydów - właśnie Krakatit. Przystępując do jego realizacji, Vávra miał już ugruntowaną pozycję $w$ tamtejszym kinie (pracował intensywnie także w epoce Protektoratu Czech i Moraw, ale, co warte podkreślenia, nie dla propagandy hitlerowskiej), uchodził przy tym za twórcę sprawnego warsztatowo, intelektualistę, który lubi mierzyć się z rodzimym materiałem literackim, o czym świadczyła też jego adaptacja Pacjentki doktora Hegla (1931, wyd. polskie 1949) jako Przeczucia (1947) według Marie Pujmanovej, ważnej pisarki czeskiej, podejmującej jeszcze przed II wojną światową tematykę psychologiczną $\mathrm{w}$ ujęciu realistycznym, portretującą w swej twórczości zwłaszcza środowiska mieszczańskie. Podejmując decyzję o przeniesieniu na ekran prozy Karela Čapka z lat 20. mierzył się nie tylko z uznanym artystą i nowoczesną literaturą tamtego okresu, ale wprowadzał też nową konwencję filmową na czeskim gruncie - science fiction. Wcześniejsze czechosłowackie adaptacje twórczości autora R.U.R. nie tyle nie przyniosły udanych rezultatów, bo przeczy temu Hordubal, zrealizowany przez Martina Friča w 1938 roku, co wiązały się z ekranizacją jego sztuk teatralnych (Loupežnik z 1931 roku Josefa Kodlička; Bílá nemoc z 1937, autorstwa Hugo Haasa). To jednak przede wszystkim utwory prozatorskie - Fabryka absolutu czy Inwazja jaszczurów dowodzą, iż dorobek literacki Čapka należy do szeroko rozumianej formuły fantastyki literackiej. Nie dziwi więc fakt, że jedna z bardziej udanych powieści pisarza, dystopijny Krakatit, został wykorzystany do poszerzenia spektrum gatunkowego czeskiego filmu. Chociaż utwór ten nie należy do kanonu tego typu literatury to, jak pisze znawczyni tematu Joanna Czaplińska: „Krakatit jest kolejną przestrogą Čapka dla ludzkości, ale zawiera prekursorski dla późniejszej fantastyki naukowej motyw odpowiedzialności naukowca za następstwa swoich poczynań" (Czaplińska 46). Historia inżyniera Prokopa poszukującego tajemniczego, tytułowego preparatu przypominała w swej powierzchniowej warstwie opowieści sensacyjno-przygodowe, ale $\mathrm{w}$ istocie, jak zazwyczaj u Čapka, miała głębszy wymiar moralny. Dotyczyła m.in. ceny, jaką ponosi każdy, kto musi zająć się zadaniem służącym całej ludzkości lub mogącym przynieść jej zagładę; tą ceną jest oczywiście osobiste szczęście. Humanizm pisarza wykorzystał Vávra wpisując go w kontekst współczesnych reżyserowi wydarzeń geopolitycznych, to jest zrzucenia przez Amerykanów bomby atomowej na japońskie miasto Nagasaki i konsekwencji tej decyzji dla losów świata i nastrojów społecznych.

Kino światowe bardzo szybko podjęło ten temat, spotęgowawszy go wkrótce kontekstem zimnej wojny i rywalizacji dwóch światowych mocarstw - USA i ZSRR. Tak było między innymi w filmach: Dzień, w którym zatrzymała się Ziemia (1951) Roberta Wise'a, Ostatni brzeg (1959) Stanleya Kramera czy Panika w roku zerowym (1962) Raya Millanda. Film czeskiego twórcy w pewnym stopniu wyprzedził ten nurt, ale i pozostał słabo dostrzeżony, zatrzymując się w pół kroku 
między szlachetnym przesłaniem (później często silnie zideologizowanym) a wymogami „kina atrakcji”, które przy tym temacie starało się być spektakularne od strony samego kształtu widowiska, oferując widzom obraz grzyba atomowego lub/oraz wizję świata postapokaliptycznego. Pisał o tym, może nadmiernie krytycznie, Andrzej Kołodyński, uznając film za zabłąkany z innej epoki kina:

Na ekranach triumfował realizm, publiczność chciała oglądać filmy oddające prawdę o dramatycznych latach niedawnej wojny, o której mówiono, że była ostatnią; we Włoszech rodził się neorealizm, którego twórcy wyszli z kamerami na ulicę, aby zmieszać się $\mathrm{z}$ tłumem. Przestroga zawarta $\mathrm{w}$ fantazji o niebezpieczeństwie, jakie sprowadzić może na ludzkość geniusz upartego wynalazcy, nie budziła zainteresowania. Trzeba było lat, trzeba było wstrząsających raportów z Hiroszimy i narastającej grozy <zimnej wojny>, aby kino podjęło temat na nowo. I nie tylko temat nuklearnego zagrożenia, lecz przede wszystkim tego, co będzie potem. Co czeka Ziemię po katastrofie? Co czeka ludzi? Dopiero u progu lat pięćdziesiątych zaczęły powstawać filmy, których twórcy potrafili się zmierzyć z tym, co niewyobrażalne (Kołodyński 121).

Krytyk ma rację, gdy mówi, że dopiero za moment - w latach 50. - powstaną pierwsze filmy postapokaliptycznego nurtu SF, w rodzaju: Pięcioro (1951) Archa Oblera, Dzień końca świata (1955) Rogera Cormana czy, wspominany już, Ostatni brzeg, ale przeczy sam sobie twierdząc, że trzeba było czasu, aby takie utwory powstały, że jednak trzeba dostrzec pewien rys prekursorstwa filmu czechosłowackiego artysty. Choćby fakt, że scenograficznie (atelierowy charakter scenografii) i operatorsko stara się nawiązywać do tradycji kina ekspresjonistycznego, a właściwa akcja umieszczona została w spajającej ją klamrze, jaką jest tu gorączkowy czy senny stan głównego bohatera, który śni jakoby całą swą historię. Wnikliwy autor eseju o Krakatit Mariusz Guzek zauważa, że:

Losy inżyniera Prokopa mają też tajemnicę, której rozwiązanie może być przedmiotem rozmaitych strategii interpretacyjnych. Skoro przypisywane jest Vávrze wykorzystanie ekspresjonistycznej faktury, to uzasadnione będzie odwołanie się do Gabinetu doktora Caligariego (Das Kabinett der Doktor Caligari, 1919) w reż. Roberta Wiene, w którym fantastyczna narracja ujęta $\mathrm{w}$ ramę opowieści szaleńca czyni przekaz niejednoznacznym i metaforycznym (Guzek 15).

Patrząc najszerzej na przekładowe zabiegi z języka literatury na język kina, jakich dokonał Vávra, trzeba podkreślić inną wymowę jego filmu. W odróżnieniu od literackiego pierwowzoru, jest ona bardzo pesymistyczna, co podkreślają nie tylko końcowa scena wybuchu atomowego i mroczna wizja przemysłu zbrojeniowego, ale również, inaczej niż u Čapka, brak dobrego, czyli sprawiedliwego, Boga, który w powieści miał taki charakter, był bogiem ludzi prostych i przeciętnych, który potrafiłby naprawić wykolejony świat (zob. Guzek 16). W filmie Stwórcy nie ma właściwie wcale, ale nie powinno nas to dziwić: moment powstania utworu i akces 
Vávry w szeregi komunistów nie pozwalają mieć tu pretensji. Czescy filmowcy wkrótce mogli już tylko filmować scenariusze akceptowane przez władzę, jednak poziom indoktrynacji był różny, o czym świadczy twórczość Karela Zemana.

Ten czeski plastyk, twórca plakatów i reżyser filmowy stał się dziś zarówno klasykiem animacji, jak i jednym z mistrzów ekranowej fantastyki. Wypracował własny, oryginalny styl nawiązujący do poetyki filmów Mélièsa w śmiałym, bezpretensjonalnym wykorzystaniu wszelkiego rodzaju trików, wzbogacanych odwołaniami do XIX-wiecznej plastyki, ilustracji do powieści Julesa Verne'a, jednego z jego ulubionych autorów (patrz także: Skradziony balon, 1967), jak również cenionego przez innych reżyserów czechosłowackich po II wojnie światowej (np. Tajemnica Stalowego Miasta, reż. Ludvik Ráža; Tajemnica zamku w Karpatach, reż. Oldrich Lipský, 1981). Często łączył animację z filmem aktorskim, osiągając jedyny w swoim rodzaju efekt. Apogeum pierwszego okresu jego twórczości stanowi właśnie Diabelski wynalazek, który w 1958 roku w wielkiej skali pokazał jego możliwości. Przenosząc na ekran mniej znaną powieść francuskiego pisarza, świadomie odwołał się do konwencji retro nie tylko w zakresie plastyki, ale też w dużej mierze sposobu myślenia odbiorców sztuki autora Tajemniczej wyspy. Trzon fabuły filmu podąża za wersją powieściową, koncentrując się na profesorze-wynalazcy i jego asystencie, dla dobra świata pracujących nad uzyskaniem energii, jednak omamionych niecnymi działaniami hrabiego i jego kompanii. Finał przynosi autorefleksję głównego bohatera i poświęcenie życia dla dobra ludzkości oraz zniszczenie wynalazku i jego potencjalnych, zbrodniczych posiadaczy. Z dzisiejszej pespektywy nie mamy wątpliwości, że takie zakończenie wpisywało się w tamtym czasie $\mathrm{w}$ kontekst geopolityczny i, raczej mimowolnie, ideologiczny. Pisali o tym Adam Garbicz i Jacek Klinowski:

...film, który stał się prawdziwym wehikułem czasu (co jego reżyserowi nie uda się już nigdy potem, pomimo kilkakrotnych prób), pozwala odkryć jeszcze jedno: że Verne zawarł w swoich fabułach wcale niebłahe refleksje uniwersalne, $\mathrm{w}$ tym wypadku o odpowiedzialności naukowców wyzwalających moce zniszczenia. Brzmi to szczególnie aktualnie w kończącej się już na szczęście epoce największego strachu atomowego czemu dodatkowego akcentu przydało wydelegowanie filmu przez Czechosłowację na brukselski festiwal roku 1958, zorganizowany z okazji Wystawy Światowej; Diabelski wynalazek zdobył tam Grand Prix. Tak oto finezyjny, poetycki przekaz ze świata dziewiętnastowiecznej fantazji stał się głosem na rzecz pokoju w środku dwudziestego stulecia (Garbicz, Klinowski 327).

Jednak ta swoista poetycko-malarska mieszanka nie mogła (i nie może dzisiaj) pretendować do miana prawdziwego, „twardego" kina SF. To wizja poety sięgającego do przeszłości, którego utwór inni wykorzystują do komentowania teraźniejszości. Ciekawe i znamienne, że spore novum pod tym względem przyniósł film 
wyzwalający się z socjalistycznych okopów i nawiązujący do dokonań polskiego pisarza Stanisław Lema.

Zwróćmy wstępnie uwagę na fakt, że recepcja twórczości Stanisława Lema na ekranie kinowym i telewizyjnym daje świadectwo niezmiennie inspirującej obecności jego dzieła w ciągu kilkudziesięciu lat obcowania zarówno z jego wymiarem artystycznym, jak i filozoficzno-naukowym. Obecność ta nie jest jednak tak obfita, jak można by się spodziewać po klasie, a także rozmiarze dorobku prozaika. Do twórczości Lema filmowcy podchodzili często z pewną rezerwą (Śledztwo z 1973 roku w reżyserii Marka Piestraka, polsko-radziecki Test pilota Pirxa z 1978 roku tegoż filmowca), nie dość odważnie, by zaproponować oryginalny ekwiwalent jego utworów, albo też - rzadziej - dość swobodnie, pozwalając sobie na spore odstępstwa od pierwowzorów (Szpital Przemienienia Edwarda Żebrowskiego, 1978 r.). Ten drugi wariant dominuje $\mathrm{z}$ kolei $\mathrm{w}$ światowych dokonaniach adaptacyjnych twórczości Lema, poczynając od Solaris (1972) Andrzeja Tarkowskiego, poprzez animowaną Maskę (2010) reżyserskiego duetu - braci Quay, aż po aktorsko-animowany Kongres (2013) Ariego Folmana z Izraela według Kongresu futurologicznego. Kluczowe zagadnienia humanistyczne, takie jak choćby kwestia możliwości poznawczych człowieka czy jego tożsamości, sprawa relacji realne - wirtualne, obecność i status sztucznej inteligencji w otoczeniu ludzkim, wreszcie wyłaniający się z tej twórczości model istnienia posthumanistycznego, stały się wyzwaniem, których zawsze potrzebowała filmowa fantastyka, a co z takim trudem udawało jej się, także dzięki twórczości autora Solaris, podjąć i realizować. Jeśli dodatkowo wziąć pod uwagę silnie obecną warstwę dyskursywną w utworach nowelowych i powieściowych Stanisława Lema, a często całkowicie podporządkowany tej formie charakter jego wypowiedzi artystycznej (eseje, rozważania filozoficzne, publicystyka), okazuje się, że nie bez pewnej dozy racji pisarz uchodzi za afilmowego, co, jak stwierdziłem powyżej, stało się dla adaptatorów zarówno barierą, jak i wyzwaniem, któremu chciano i nadal chce się sprostać.

Pierwsze filmy, jakie powstały na podstawie twórczości autora Niezwyciężonego, wynikały z uwarunkowań geopolitycznych, a także dominującej poetyki realizmu socjalistycznego, której wyznaczniki stylistyczne i tematyczne odcisnęły piętno zarówno na utworach pisarza, jak i dziełach filmowców. Dotyczy to pierwszej wydanej w formie książkowej powieści fantastycznonaukowej Lema Astronauci (1951) oraz jej wersji kinowej Milcząca gwiazda (1960) Kurta Maetziga (reżysera z NRD) oraz drugiej z kolei wydanej w tej formie powieści Obłok Magellana przypomnę, z 1955 roku - i filmu Ikaria XB-1 (1963). Astronauci pojawili się na polskiej scenie literackiej nie tylko w czasie tryumfującego komunizmu (i zbrodniczego stalinizmu) i w czasie narzuconej twórcom metody socrealistycznej, ale też, w momencie, w którym artysta wierzył w lepszą przyszłość świata, a drogą do niej miała być wiedza, służąca definiowanej zgodnie z filozofią oświecenia moralności. 
Wiara w konieczność postępu, a także w jego budującą wartość fundowała nowoczesne, pooświeceniowe myślenie, którego częścią była także potrzeba kreowania utopii. Ideologia prowadzącego do określonego celu postępu na dobre i złe zagościła w epoce nowoczesnej. Zauważono przy tym, że istnieją pewne koszty przyjęcia takiej ideologii. Była nią cena, jak to ujął jeden $\mathrm{z}$ badaczy nowoczesności: „podporządkowania człowieka i wspólnoty normom instrumentalnej racjonalności" (Nycz 5). Gdzie tu miejsce dla doktryny realizmu socjalistycznego, który poniekąd - zaistniał jako remedium na burżuazyjny modernizm, a jednocześnie ( $w$ ramach nowego modelu kultury totalitarnej) wpisywał się $\mathrm{w}$ założenia tzw. klasycznego modernizmu? Z pewną dozą ostrożności można powiedzieć, że $\mathrm{w}$ wersji soc był jego wersja radykalną lub, jak chce tego np. Jerzy Jarzębski (Jarzębski 42), karykaturalną. Co do tradycji utopii literackiej, którą przywoływał Lem, znawcy zagadnienia podkreślają, że mieliśmy w tym czasie do czynienia z pewnym paradoksem, który daje się jednak wytłumaczyć. Otóż:

Socjalistyczny system w Polsce przyznawał się do historycznych antecedencji odnajdywanych w Państwie Platona, u utopistów renesansu i ich siedemnastowiecznych naśladowców, wreszcie $\mathrm{w}$ tradycji socjalizmu utopijnego. Oczywiście nie zmieniało to faktu, że marksizm nie mógł być w latach stalinowskich traktowany $\mathrm{w}$ jakimkolwiek stopniu jako utopijna wizja państwa, ani że koncepcja materializmu historycznego, zakładająca pełne poznanie mechanizmów dziejowych i przewidywalność przyszłości, sama również stanowiła rodzaj utopii (Brzóstowicz-Klajn 128).

Utopie komunistyczne, takie jak Astronauci i Obłok Magellana, przedstawiały naukę jako narzędzie przekształcania codziennej rzeczywistości. Ateizm i racjonalizm, które odnajdziemy u pisarza, przez pewien czas szły w parze z optymizmem poznawczym, i takąż opinią na temat roli i charakteru człowieka, kierującego się równolegle do rozwoju cywilizacyjnego - postępem etycznym. Ale Lem dość krótko dawał się uwodzić quasi-utopii, w jakiej przebywał, stąd też - być może sam nie wykreował ich wiele. Łączenie racjonalizmu z idealizmem, odwoływanie się do ludzkich tęsknot za rajem zderzyło się z otaczającą rzeczywistością, która nijak miała się do powieściowych wizji i obietnic, wynikających z wiary w postęp.

Wiele łączy adaptacje filmowe dokonane na podstawie obu książek. Milczaca gwiazda z początku dekady lat 60. ubiegłego wieku autorstwa reżysera z NRD Kurta Maetziga powstała na bazie scenariusza napisanego z Janem Fethke. To polskowschodnioniemiecka koprodukcja, podążająca mocno za antywojennym przesłaniem, jakie znajdziemy w Astronautach. Tak jak w powieści, z naszej planety wyrusza statek kosmiczny Pantokrator z misją odnalezienia wysoko rozwiniętej cywilizacji na Wenus, ale okazuje się, że w wyniku wybuchu, prawdopodobnie neutronowego, życie na tej planecie zostało zniszczone, zresztą - tuż przed planowaną inwazją Wenusjan na Ziemię. Film zrealizowano $\mathrm{z}$ dużym rozmachem inscenizacyjnym i technicznym (zapewne dzięki możliwościom berlińskiej DEFY), 
robiącą wrażenie scenografią (ze strony polskiej autorstwa Anatola Radzinowicza), konsekwentnie podporządkowaną stronie wizualnej muzyce Andrzeja Markowskiego. Wiele też, niestety, znajdziemy wad, zwłaszcza w uproszczeniach fabularnych i deklaratywnych dialogach, które często przypominały przemówienia, a przede wszystkim słabości polegających na pozbawieniu filmu niuansów dotyczących motywacji postaci oraz odtwarzaniu historii Wenusjan. Całość prowadzi do prostej, propagandowej myśli, negującej zbrojenia i wszelkie inne owoce kapitalizmu.

Przypadek powstałego trzy lata później czechosłowackiego filmu Ikaria XB-1, w reżyserii Jindřicha Poláka jest nieco bardziej skomplikowany, choć rezultat podobny. Brak informacji $\mathrm{w}$ czołówce o inspiracji powieścią Lema, nie zmienia faktu, że powstał po lekturze Obłoku Magellana. Wzorem książki opowiada o wyprawie badawczej do innego układu solarnego tytułowego statku kosmicznego, z kilkudziesięcio- czy nawet kilkusetosobową, międzynarodową (jak w Milczącej gwieździe) załogą. Ikonografia tego filmu spełnia podstawowe wymogi ówczesnego kina SF, poczynając od samego tytułu, poprzez charakterystyczne rekwizyty, takie jak statki kosmiczne, niezwykłe urządzenia (zwłaszcza komputery), roboty, broń, dalekie światy etc. Ponadto istotną rolę w filmach z gatunku SF odgrywają naukowcy, a ich działalność jest mocno utożsamiona z techniką, mogącą służyć człowiekowi lub - odwrotnie - unicestwić go. Film ujmuje do dzisiaj widza wiarygodnym obrazem życia codziennego na pokładzie, relacji międzyludzkich, psychologii osób lecących w nieznane i niebezpieczne miejsce, spędzających ze sobą dużo czasu. Równie ważna jak sztafaż fantastyczno-naukowy jest kondycja moralna i emocjonalna człowieka-badacza i człowieka-zdobywcy, tu w gruncie rzeczy nie tak daleka od wykonującego inną profesję. Również sposoby bycia, zwyczaje i rytuały nie odbiegają od "ziemskich": podróż w kosmos to zadanie do zrealizowania dla pracowników-astronautów. Można by rzec: mniej przygody i batalistyki, a więcej obrazu naturalnie funkcjonującej powszedniości (swoją drogą jakże to czeska cecha filmowa!). Pod tym względem utwór nie ustępuje miejsca dziełom zachodnim z tego okresu, starającym się nadać ekranowej fantastyce rys realizmu, mający być kontrapunktem dla Mélièsowskiej cudowności i efekciarstwa. Słusznie dostrzegał istotę zalet utworu cytowany już Kołodyński:

Film przestawia proces psychologicznej interakcji polegającej na przekształcaniu się reakcji indywidualnych w zbiorowe. Po czterech miesiącach podróży u ludzi pojawiają się oznaki znużenia, lęku przed kosmiczną pustką i dramatyczny konflikt dotyczy właśnie sposobów ich przezwyciężania. Technologia ustępuje na plan dalszy, najważniejszy okazuje się człowiek (Kołodyński 87).

To, co najważniejsze, wynika z Ikarii-XB-1, a wspólne dla obu filmów zrobionych na podstawie twórczości Lema, wyraża się w przesłaniu. Brzmi ono antywojennie i antymilitarystycznie, a jego uniwersalizm wiąże się z pochwałą ludzkości 
jako cywilizacji dążącej do bezkonfliktowego, racjonalnego poznania - siebie i zwłaszcza wszechświata - na ile jest to możliwe. Owym morałem wpisuje się Ikaria XB-1 w podobne tony, które odnaleźć można wśród chwalących pokój dźwięków, dobiegających zarówno z Krakatita, jak i nawet Diabelskiego wynalazku. Najmłodszy utwór w najmniejszym stopniu opiera się na umowności i podkreślaniu cudowności rozwiązań technologii przyszłości. Zamiast tego oferuje śmiały kierunek, jakim szło kino tego okresu w skali globalnej: nacisk na realistycznie ukazaną science, zgodnie $\mathrm{z}$ coraz powszechniejszym $\mathrm{w}$ dekadzie lat 60. zeszłego stulecia odczuciem, że to nauka kształtuje naszą teraźniejszość i będzie tak robić z przyszłością - na dobre i złe. Niewykluczone, że w ten sposób, nawet jeśli niedoskonały, zapowiada nadejście Czechosłowackiej Nowej Fali, która, jak inne światowe prądy modernizacyjne w sztuce filmowej, obejmowała w swej różnorodności artystycznej także bardzo mocny nurt realistyczny, chcący mówić coś prawdziwego o współczesnym człowieku. Ikaria XB-1 wyraża jego sen.

\section{BIBLIOGRAFIA}

Brzóstowicz-Klajn, Monika. Tomasz Morus w mundurku pioniera, czyli utopia i utopijność w polskim socrealizmie. Poznań: Wydawnictwo Naukowe UAM, 2012.

Czaplińska, Joanna. Dziedzictwo robota. Wspótczesna czeska fantastyka naukowa. Szczecin: Wydawnictwo Naukowe US, 2001.

Garbicz Adam, Klinowski Jacek. Kino, wehikuł magiczny. Podróż druga 1950-1959. Kraków: Wydawnictwo Literackie, 1987.

Guzek, Mariusz. „Krakatit i Ciemne słońce - adaptacje prozy Karela Čapka autorstwa Otokara Vávry". Hrabal i inni. Adaptacje czeskiej literatury. Red. E. Ciszewska, E. Nurczyńska-Fidelska. Łódź: Wydawnictwo PWSFTviT oraz Uniwersytetu Łódzkiego, 2013. S. 9-26.

Jarzębski, Jerzy. Pożegnanie z emigracją. O powojennej prozie polskiej, Kraków: Wydawnictwo Literackie, 1988.

Kołodyński, Andrzej, Dziedzictwo wyobraźni. Historia filmu sf. Warszawa: Wydawnictwo Alfa, 1989.

Nycz, Ryszard. „O nowoczesności jako doświadczeniu”. Teksty Drugie (3) 2006. S. 4-9. 